University of Nebraska - Lincoln

DigitalCommons@University of Nebraska - Lincoln

To Improve the Academy

Professional and Organizational Development Network in Higher Education

1997

Teaching Awards: The Problem of Assessing Their Impact

Nancy Van Note Chism

Borbala L. Szabo

Follow this and additional works at: https://digitalcommons.unl.edu/podimproveacad

Part of the Higher Education Administration Commons

Van Note Chism, Nancy and Szabo, Borbala L., "Teaching Awards: The Problem of Assessing Their Impact" (1997). To Improve the Academy. 375.

https://digitalcommons.unl.edu/podimproveacad/375

This Article is brought to you for free and open access by the Professional and Organizational Development Network in Higher Education at DigitalCommons@University of Nebraska - Lincoln. It has been accepted for inclusion in To Improve the Academy by an authorized administrator of DigitalCommons@University of Nebraska - Lincoln. 
Chism, N.V.N., \& Szabó, B. L. (1997). Teaching awards: The problem of assessing their impect. In D. DeZure (Ed.), To Improve the Academy, Vol. 16 (pp. 181-200). Stillwater, OK: New Forums Press and the Professional and Organizational Development Network in Higher Bducation. Key Words: Program Evaluation, Rewands, Instructional Improvement.

\section{Teaching Awards: The Problem of Assessing Their Impact}

\section{Nancy Van Note Chism}

\section{Borbála L. Szabó}

The Ohio State University

Although teaching awards are a popular approach to the reward and improvement of teaching, their impact has not been studied extensively. The studies that have been done find that they are motivational and affirming, but extensive, clear effects on teaching improvement have not been documented. Part of the difficulty in studying effects of awards involves goal complexity and vagueness. Suggested ways of studying effects begin with goals and employ a variety of approaches, ranging from interviews and surveys to document analysis.

Teaching awards have been a part of higher education for several decades. Typically, awards programs reward individuals or groups with cash payments, salary increments, plaques, funds to conduct projects, or release time. In most cases, nominees are usually judged by a committee against certain preannounced criteria for excellence. Such awards have an immediate appeal and proponents associate them with many goals focusing on the quality of instruction. Arguments for 
and against the use of awards are made in the literature, but few empirical studies of the effects of teaching awards programs have been conducted. How, then, do we know whether teaching awards are worthwhile? This paper reviews the literature on teaching awards and suggests several ways in which their impact can be further studied.

\section{Popularity of Teaching Awards}

One of the earliest teaching awards was in place at the University of California, Berkeley in 1959 (Sorcinelli \& Davis, 1996). In a national survey of 756 higher educational institutions conducted almost twenty years later, 38\% indicated using awards (Centra, 1978): for the 93 universities in the sample, this rate was much higher (79\%). Erickson (1986) later conducted a study of faculty development practices in four-year colleges and universities in the United States, finding that among the 630 institutions he surveyed, the most popular category of practice was the use of grants, awards, leaves, and exchanges. Similarly, in a survey that included institutions of the American Association of Colleges for Teacher Education, teaching awards were found to be among the top five faculty developmental activities (Uhlig \& Haberman, 1987). As cited by Menges (1996), El-Khawas found that in the ten year span from 1983 to 1993, the number of institutions reporting having teaching awards programs increased from four out of ten to seven out of ten.

\section{Why awards?}

Teaching awards programs have been initiated for a plethora of announced purposes. While ultimately it is hoped that student learning will improve as a result of teaching awards programs, awards programs focus on this goal indirectly-through teaching.

Several papers articulate reasons why institutions offer teaching awards (e.g., Chism \& Szabó, 1996; Jenrette \& Hays, 1996; Lunde \& Barrett, 1996; Menges, 1996). McNaught and Anwyl (1993) categorized these and identified three main reasons for the development of award programs, based on their sample of 24 Australian institutions. They found that more than half of the institutions in their study (14/24) responded that the main purpose of teaching awards programs is to 
recognize and reward the achievements of distinguished teachers. Awards are believed to affirm individuals and assure them that the energy and effort they invest in teaching is recognized and valued.

The second goal of teaching awards programs mentioned by the majority of respondents in the McNaught and Anwyl (1993) survey is to encourage teaching excellence across the faculty (13/24). Awards are expected to achieve this end through two activities: the self-examination that the nomination process is likely to stimulate and the dialogue that occurs in generating and applying a standardized set of criteria on what constitutes good teaching (an expectation also posed by Chism \& Szabó, 1996; Kahn, 1996; and Lunde \& Bartett, 1996).

McNaught and Anwyl (1993) found that the third purpose listed by their respondents was to promote the value of teaching as an academic activity at the institution (3/24). The belief that awards programs send a strong message to faculty, students, and the public about the institution's commitment to excellence in teaching is echoed by many programs (Chism \& Szabó, 1996; Menges, 1996).

Another goal that is set forth for teaching awards is that they provide valuable publicity for universities (Chism \& Szabó, 1996; McNaught \& Anwyl, 1993). This publicity may please legislatures and the public at large, but also may help to attract prospective professors and students (Schwartz, 1992). Positive gains can be obtained from balancing the emphasis placed on teaching and research within an institution and portraying an image of the institution as one in which teaching and research are interrelated (Edgerton, 1993; McNaught \& Anwyl, 1993).

Other goals of awards programs are identifying standardized criteria on what constitutes good teaching and selecting faculty who can provide role models for others (Forsythe \& Gandolfo, 1996; McNaught \& Anwyl, 1993). Some institutions anticipate that progressive refinements of what constitutes good teaching will be prompted by awards programs as they formulate and apply criteria. These definitions, in turn, might help the institution achieve more clarity on faculty teaching accountability issues (McNaught \& Anwyl, 1993). 


\section{Mixed Support}

Despite the popularity of awards programs, some faculty and scholars are skeptical about their potential or actual effectiveness. These reservations can be classified as conceptual objections, normative obstacles, or strategic difficulties.

\section{Conceptual objections}

Perhaps the most frequent conceptual objection is that human behavior, and particularly teaching behavior, is primarily intrinsicallymotivated. (A brief overview of the literature on intrinsic motivation as it relates to college teaching is in Paulsen and Feldman, 1995). Awards, it is argued, will not motivate teachers who do not value teaching, nor will they inspire the mediocre to greatness (McNaught \& Anwyl, 1993; Jacobsen, 1989).

A second conceptual objection is rooted in continuous quality improvement approaches: Lasting improvement comes about when inquiry and responsive action, generated by those doing the work, are a continuous part of the routine, rather than as a response to an externally-set goal. In McNaught and Anwyl's (1993) study of Australian universities, those who argued against the establishment of an award felt firmly that the emphasis should be on normal career rewards and established promotion procedures. Schwartz (1992) makes a similar argument. Jacobsen (1989) observes "If people sense that they are externally controlled, there is a potential for what was once enjoyable to lose its appeal" (p. 8).

A third objection is that collaboration, not competition, is important in educational performance considerations. McNaught and Anwyl (1993) point this out and Jacobsen (1989) cites a study by Spence and Helmreich (1983) that suggests that achievement is negatively affected when competition is introduced in a situation, such as faculty work, which is characterized by independence and intrinsic motivation.

Finally there is the argument that emphasis on awards is a trivial approach that masks the gross inequities between support for teaching and research (McNaught \& Anwyl, 1993). 


\section{Normative obstacles}

The strong norms and ethos of teaching were documented in the case of precollegiate teaching in the seminal work of Lortie (1985). These norms, which are prevalent as well in postsecondary teaching, also come in conflict with the idea of awards. One of these is the egalitarian norm, the disinclination to put one teacher forward as better than another. Examples of this norm in action include objections to merit pay, the relatively flat hierarchy of the teaching profession, resistance to "master" teachers, and the reluctance of mentors to offer direct advice and of peer reviewers to suggest changes. Teaching awards are obviously not in harmony with an egalitarian outlook (Forsythe \& Gandolfo, 1996).

Norms of privacy and autonomy are also factors that surface in objections to teaching awards. These are reflected in reluctance to discuss teaching publicly; the perceptions that "teachers are born, not made," that teaching is solely artistry or ineffable; and in resistance to the notion that there are common standards or measures against which one can measure teaching performance. Several scholars call these the "myths" of college teaching (Mauksch, 1987, Eble, 1982, and Svinicki, 1995). They imply that teaching is individualistic, idiosyncratic, personal, and noncomparable-therefore, that distinctions among teachers cannot be accurately determined.

\section{Strategic concerns}

A third cluster of concerns, related to the conceptual and normative issues just discussed, centers on strategic considerations. Several have to do with the logistics of awards: the limitations of funds compared with the abundance of possible winners (McNaught \& Anwyl, 1993; Ling \& Ling, 1994), the difficulties of coming to agreement on criteria (McNaught \& Anwyl, 1993), anxiety about perpetuating or escalating jealousies and rivalries among faculty, and the fear that the process of determining a winner will not be "fair"-that it will be contaminated by bias, political influence, unfair advantage, or sloppy evaluation methods. Another concern is the fear that winners will be branded as "teachers" and therefore not serious scholars (McNaught \& Anwyl, 1993; Sowell, 1990), The result of these con- 
cerns is that, beset by such strategic difficulties, awards will be superficial and resented. Opponents argue that, given tight budget situations, funds would be better used to improve the teaching of all faculty, rather than simply to reinforce the performance of good teachers.

\section{Results of Empirical Studies}

Despite the widespread use of awards to recognize excellence in teaching, little attention has been given to evaluating their impact. In Centra's 1978 survey, he reported that although the use of awards was a common faculty development practice, only around $27 \%$ of the respondents he surveyed attributed any positive effect to its use.

Studies that explored the actual effect of teaching awards date from the late 1980s. At The Ohio State University, an interview study (Poirier \& Sell, 1989) of award recipient faculty and their department administrators found that affirmation was a striking effect: most recipients were overwhelmed with the exemplary treatment they received. In the testimony of one: "compliments, congratulations from others...lasted a long time" (p. 2). Interviewees in general tended to describe the financial aspect of the awards as important, yet did not perceive them as having much impact on promotion and tenure decisions. The respondents observed that the awards did motivate them to sustain their efforts. While there appeared to be clear benefits for faculty, the perceived benefits to academic units were less obvious. Responses of administrators about the impact of the award on recipients or their departments were mixed. Although most were supportive of awards, some felt that awards might actually be counterproductive because they recognize a few faculty to the exclusion of many others.

In the same year, a study was completed on the faculty incentive program at Messiah College (Jacobsen, 1989) to determine if the implementation of the program had an impact on the quality of teaching at the college. Using scores from the IDEA faculty evaluation system, three groups of participants were compared: faculty who received the award ( $n=12)$; faculty who applied but did not receive the award $(n=10)$; and faculty who did not apply $(n=30)$. The study found that aggregate scores on the institutional level remained constant over the semesters studied. Individual scores of those who received the 
award (which were much higher than the nonapplicant group and slightly higher than the nonrecipient group) increased only slightly (4.8\%) in the period following their award. Scores for nonapplicants, similarly, increased only slightly (5.9\%). Scores for the non-recipient group changed the most, a $15.5 \%$ increase. The results, on the one hand, confirmed that the awards were distributed to faculty who were significantly more effective in teaching than their colleagues, but on the other hand, did not indicate that the overall quality of teaching performance at the institution was improved by the existence of an awards program. Applying for, but not receiving the award, seemed to have a stronger motivational force for improving teaching skill, whether as a result of the internal drive to win next time or to prove oneself capable and worthy regardless of the outcome of the competition.

Schwartz (1992) explored the relationship between receiving an award and promotion or merit increase in salary through interviewing award winners about their perceptions of the effects the award had on their status, advancement, pay, or other rewards. He found that only $2 \%$ of his sample felt that winning an award affected them negatively, while $48 \%$ felt that there was very little or moderate effect and $7 \%$ that the award affected their advancement very positively. (These findings contradict the widespread "urban legend" warning that teaching awards are the "kiss of death" - that they brand recipients as "teaching dogs" who are incapable of serious scholarship and therefore throw themselves into teaching.)

In a 1991 interview study of awards for multicultural teaching, lopez and Chism found that recipients expressed being "surprised" and "flattered," having "feelings of tremendous pleasure," and being "touched by the ceremony." They felt that the award reinforced their commitment to teaching because, as one indicated, winning the award "makes you feel like you have to maintain your reputation." Many of the recipients, nevertheless, indicated that although they were pleased with receiving the award, they were highly dedicated to good teaching prior to receiving the award and would have shown this level of effort whether or not there were an awards program.

Ling and Ling (1994) investigated the efficacy of an awards program at an Australian university. Applicants and department chairs 
reported that the awards were "very motivational:" they affirmed the efforts of the faculty and also presented them with an opportunity to contribute to the profession. The study reported mixed findings on the extent to which the awards program stimulated conversation about teaching: although the program prompted little or no formal discussion at the department, a process of informal discussion did occur, especially in departments in which two or more faculty applied for the award. The study also concluded that because this program left criteria for judging effective teaching open-ended, the definitional process that resulted raised "sensitivity in the institute to what constitutes high quality teaching" (p. 243).

In a 1996 survey involving 346 two-year colleges, administrators were asked about their perceptions of the benefits derived from programs to recognize exemplary teaching (Jenrette \& Hays, 1996). Respondents identified one or more of the following effects of award programs: enhancement of student learning, elevation of faculty morale, the encouragement and promotion of high-quality teaching, positive publicity, encouragement of ongoing professional development, and recognition of individual teachers on all levels (department, institutional, state, and national).

In a recent survey (Chism \& Szabó, 1996) at one institution in which department teaching excellence award candidates were interviewed, most of the respondents felt that the process of nomination neither raised their awareness about the importance of teaching nor initiated discussion on the topic, but rather affirmed them and deepened their commitment. Most reported that their departments already valued teaching and were in a constant state of self-evaluation and self-improvement. Those who received the award, however, initiated efforts to continue to improve teaching because they received funds to do so.

Results from a study of the impact of departmental awards at another university were somewhat more positive (Kahn, 1996). Chairs of winning and nonwinning departments agreed that the process of preparing the nomination portfolio was valuable and informative and promoted much discussion. They also felt that winning the award generated considerable publicity, thus advancing student and faculty recruitment and increasing teaching morale in the department. 
In sum, there are not many published impact studies, considering how common awards programs have come to be. The studies that have been done focus largely on the winner's perceptions of the effects of the award on them personally. Given our culture's deep-seated belief that reinforcing behavior will obviously have good effects, the difficulties involved in researching the impact of teaching awards, and the likelihood that the studies that have been done are specific to individual institutions, it is no small wonder that there is not an extensive literature on the effects of teaching awards. The benefits seem too obvious to research, while at the same time, the task of documenting these benefits appears too elusive. As awards programs proliferate, however, it becomes more important than ever to establish a rationale for these awards that is explicit and well conceived. To do this, more systematic study is warranted.

\section{How Can the Impact of Awards Be Studied?}

Impact studies traditionally begin with goals, although a goal-free approach (Scriven, 1973) in which effects are assessed independent of goals, is also a viable approach. In the case of awards programs, where goal claims are common and causal links very obscure, it would seem logical to first look at goals before exploring unintended effects. As indicated above, awards programs are implemented for several reasons, six of which will be used to frame this discussion of how impact might be assessed. These include: affirming good teachers, rewarding them, improving teaching, improving learning, improving the campus climate for teaching, and improving public perceptions of the quality of teaching and climate for teaching at the institution.

\section{Affirming good teachers}

How would one judge whether an awards program affirms the efforts of those who have become excellent teachers? This seems to be one case where self-report is clearly the method of choice, for who but the teachers themselves can report on whether they feel affirmed or not? Indeed, in the small body of studies that exists on the impact of awards, this is one clear theme that emerges: teachers attest to the affirmation they feel when they win an award (Chism \& Szabó, 1996; 
Kahn, 1996; Ling \& Ling, 1994; lopez \& Chism, 1991; Poirier \& Sell, 1989). Often, this affirmation is tinged with resentment that the efforts were unrewarded in the past or personal modesty that causes embarrassment at having been singled out as more excellent than their peers, but there is nonetheless gratitude and a sense of (finally) feeling appreciated that is engendered by the recognition that the award brings. Interviewing winners or asking them to complete an openended survey are appropriate ways to judge whether this goal has been reached. Unanticipated effects related to affirmation are also likely to surface when these open-ended methods are used.

\section{Rewarding good teachers}

In addition to personal affirmation, most awards programs use language that suggests that in addition to recognition, some form of reward will accrue to the winners. In most cases, this is cash or a plaque or both; in the case of programs that give grants to the winners, it might be resources to pursue a project or release time. Simple documentation that the stated reward has been bestowed is the obvious approach to assessing goal-attainment here: Did the winner get the check, plaque, release time, or other promised reward? Beyond this, however, one could ask about the broader reward system. Were promotion and tenure and merit pay decisions influenced positively by the award? Were teaching assignments, committee leadership, and other decisions made with an eye to respecting the expertise of the winner and rewarding their work? Although it would be relatively easy to explore these issues by tracking the progress of winners versus nonwinners on these dimensions, there is little evidence other than the 1992 Schwartz study cited above that these studies have been conducted.

\section{Improving teaching}

A stated or implicit goal of many awards programs is that they will improve teaching. One can look at this in at least two ways: improving the teaching of the winners by encouraging them to continue their pursuit of excellence, or improving the teaching of others by encouraging them to emulate the winners or to increase their efforts 
so that they will be competitive for the award in the future. These will be discussed separately.

Improving the teaching of the winners. In order to explore whether a teaching award improved the performance of a recipient or not, one would have to look at some baseline data and then for evidence of progress beyond that measure. How would this be done? One approach that has been used is self-report, asking teachers if they have improved or increased their commitment following receipt of an award. The findings that are documented (Chism \& Szabó, 1996; lopez \& Chism, 1996; Poirier \& Sell, 1989) are fairly negative: the majority of respondents indicate that their teaching efforts are intrinsically motivated and that the quality of their effort and performance was high before the award and continued to be high afterward. Most say that the award made no difference in their performance. Beyond self-report, one would have to look at evidence of improvement through traditional teaching evaluation methods, such as results of student ratings, peer review, and documentation of effort through a teaching portfolio. Although this would constitute the most systematic approach, it would be quite complex and time-consuming. A more practical method might be a comparison of reflective statements on teaching effort and performance taken at the time of the award and at some time afterward. Such statements would be self-report, but could be triangulated by having them reviewed by knowledgeable peers who could comment on how they fit with their own perceptions and observations. All of these approaches, however, rely on establishing a causal link between the award and the resulting improvement (or lack of improvement), which would be quite difficult, because many other factors could account for changes in performance.

Improving the teaching of others. Similarly, exploring whether the existence of the awards program improved the teaching of nonwinners would involve self-report (did they make efforts to work harder or try innovative approaches so that they would be viable candidates for the award?); examination of teaching performance as documented by scores, portfolios, reflective statements, and the like, as well as baseline comparison; and the establishment of a connection between the awards program and the resulting improvement or lack thereof. All of 
these would be quite complex, although pieces of this research have been done, as exemplified by Jacobsen, 1989, cited above.

The argument that awards programs will encourage reflection on the part of nominees as they prepare their applications is also frequently made, and can be explored through self-report. As indicated above, some studies that have looked into this (Chism \& Szabó, 1996; Ling \& Ling, 1994) find mostly negative results: applicants report that they put together their submissions in haste without much dialogue and reflection, and often use text put together for other purposes. Kahn (1993), however, had more positive findings.

\section{Improving learning}

As has been argued elsewhere (e.g., Angelo, 1996; Chism \& Lumpkins, 1995), linking a given intervention to improvements in teaching and then linking these to improvements in learning is an exceptionally difficult research task. The complexity of the teachinglearning connection and the variety of factors that are not controlled by the teacher in this interaction renders the prevailing common sense inclination to assume that a change in teaching will produce direct effects on learning somewhat questionable. What would be required is baseline documentation of learning, establishment of a documented increase in learning at some later time, and linkage to the awards program as a causal influence. This would have to be done on a case by case basis, because it would be unreasonable to assume that aggregate institutional-level student performance data could be linked exclusively with the existence of an awards program, given the many other possible factors.

\section{Improving the campus climate for teaching}

Climate is always particularly difficult to explore, partly because it is so elusive a concept. One can approach this on several levels in the case of teaching awards, such as (1) perceptions of the faculty on the extent to which teaching is valued, (2) resource allocation, and (3) influence. To explore whether perceptions about the value of teaching have changed, campus surveys have been done (Grey, Diamond, \& Adam, 1996), but once again, it is difficult to attribute the documented 
changes to the establishment of teaching awards. Menges (1993) suggests that documenting whether the number of applications for the award increase would be another way to assess climate change, as would documenting increases in reflective conversation about teaching, instructional innovations, and the number of teaching and learning issues on agendas of departmental meetings.

Similarly, changes in resource allocation can be detailed to discover whether more financial and human resources are dedicated to teaching before and after awards programs. Here, the overall causal attribution would be hard to establish, but the direct allocation of funds for the awards program is certainly one instance where the link is obvious. In the case of some programs, such as the departmental awards program that Chism and Szabó (1996) document, the resource allocation, in this case nearly $\$ 3$ million over ten years, is substantial: The shift of resources to support teaching is clear-cut. In the case of others, where small amounts of cash are tied to the program, the connection is less striking.

Influence can be documented in several ways: self-report, report of peers, and documentation of the rise of award winners to positions of influence following their award. Self and peer report were used in the lopez and Chism (1991) study to document the extent to which having won an award increased the informal influence of winners. Modest positive findings were reported. In cases where award winners become members of a teaching academy or automatically assume a leadership or mentoring role as part of the award, influence is more likely to occur and to be documentable in the form of activities that take place following the award, such as representation of award winners on decision-making bodies or committees connected with teaching issues (Chism, Fraser, \& Arnold, 1993). In these cases, linking the effect to the cause is somewhat easier, because faculty receive the positions of influence because they have won the award.

To explore this potential effect of teaching awards in improving public perceptions of teaching quality at the institution, one would have to look at whether news of the award reaches the public and whether this changes perceptions. Menges (1996) lists several indicators that could be used to document receipt of the message, including extensive media coverage about the awards and better informed 
behavior on the part of legislators. He also suggests some indicators that might reveal that perceptions were changed, such as more external funding, and some indicators that the awards enable the institution to point to specific ways in which they support teaching, such as improved ability to answer parent questions at orientations or to promote quality of teaching in recruiting. All of these could be assessed through documentation of media coverage, changed legislative behaviors, and the like. Once again, however, linking changes in perceptions to the existence of an awards program would be difficult.

\section{Unanticipated outcomes}

Particularly when naturalistic methods of inquiry, such as interviews, are employed in assessing effects of awards programs, unanticipated outcomes come to the researcher's attention, adding a goal-free dimension to the study. For example, in the Chism and Szabo (1996) study of departmental teaching awards, one department reported that it began to use the portfolio it had prepared for its selfnomination as a recruiting tool to alert candidates for new positions that the department was serious about teaching. Another reported that it did not have any alumni data to put in its self-nomination portfolio, which stimulated the department to initiate a practice of regular alumni surveys. Kahn (1996) reports similar effects on faculty recruitment as well as student recruitment, and details other unanticipated, positive outcomes of the program at her institution.

\section{Conclusions}

In evaluating program impact, pragmatic concerns loom large: are there sufficient resources to evaluate program impact well? A rule of thumb is that major funded programs should devote about ten percent of their budgets to program evaluation, but in times of scarce resources and in the case of internally funded initiatives, even these limited resources are hard to come by. It is doubtful that the studies mentioned above could be conducted thoroughly by every institution with an awards program. What are some possible solutions?

- Conduct limited studies. At a minimum, institutions with awards programs can periodically conduct short interviews or collect 
open-ended survey responses from both winners and nonwinners of awards to assess self-reported impacts. Although they are subject to the limitations of self-report, such efforts are informative about the causal link because they ask about this directly and can uncover unanticipated outcomes because they rely on openended questions.

- Extrapolate from existing studies. Because systematic studies take a great deal of effort, they should inform the field rather than only the specific instance that prompted them. Quite obviously, they have to be published in order for others to benefit from them. Urging the publication of these studies is thus a critical first step. Although statistical studies conducted in one setting are not, strictly speaking, generalizable to another, they certainly can suggest patterns. Qualitative studies that describe the context and results in detail can enable readers to make the transfer to their settings as they judge the extent to which their situation is like or unlike the setting described in the study.

- Reduce the size of claims. Judging from existing studies, it seems safe to say that awards affirm the efforts of good teachers and encourage them to continue to perform well. It is less clear that other claims should be made, even though they have some face validity.

- Design programs to maximize the possibility that desired effects will happen and build in an assessment component. A number of suggestions for optimizing the effects of awards programs arise from evaluative studies and theoretical speculations in the literature. A first is to increase the number of recipients so that competition is not highlighted and effects are spread over many faculty (Edgerton, 1993; Weimer, 1990). Other suggestions (Edgerton, 1993; McNaught \& Anwyl, 1993, Menges, 1996; Svinicki \& Menges, 1996) attempt to make awards programs emphasize collaboration (e.g., granting rewards more frequently to course teams). Furthermore, Menges (1996) points out that an award needs to be future oriented by enabling further attainments. To furnish the awards program with a future orientation without turning it into a grants program, a few writers suggest involving award winners in forums and committees (e.g., teaching acade- 
mies) devoted to promoting the value of teaching and a sense of community (Chism, Fraser, \& Amold, 1996; Edgerton, 1993; Green, 1990). Optimizing the value of the award may also require personalizing it to convey the message to the recipients that what they contribute is recognized (Weimer, 1990). Other suggestions for refinement include establishing more clear and open selection criteria in order to allay suspicions about the objectivity and accuracy of the process (Menges, 1996; Weimer, 1990). Selection criteria need to fit the mission of the institution as well as be grounded in research to avoid favoritism and popularity (Menges \& Svinicki, 1996).

- Invest in other programs. Opponents of teaching awards often propose other approaches that they suggest will be more effective. Concerned that all kinds of one-shot awards have few lasting effects, many commentators argue instead for grants programs through which individuals or groups of people can receive funding to implement a new project (Ling \& Ling, 1994). Zahorski (1996) argues for the special case of classroom research, pointing out that if faculty were awarded resources to inquire into classroom questions, this activity would receive the prestige associated with other forms of scholarship. Another proposed alternative to awards programs is certification (Smith \& Walvoord, 1993), which would make judgments about the teaching excellence of faculty according to predetermined criteria and award certificates of excellence in teaching to those who are deemed worthy.

Finally, it is important to recognize that the absence of findings that establish a clear link between awards and improved instruction on any level is not necessarily an inherent failure of awards programs. Rather, the problem lies in judging how, in a given environment, these programs should be implemented in order to achieve their stated goals and in finding appropriate ways to assess their effects relative to the goals.

\section{References}

Angelo, T. A. (1990). Relating exemplary teaching to student learning. In M. D. Svinicki \& R. J. Menges (Eds.), Honoring exemplary teaching (New Directions for Teaching and Leaming No. 65) (pp. 57-64). San Francisco: Jossey-Bass. 
Centra, J. A. (1978). Faculty development in higher education. Teachers College Record, 80, 188-201.

Chism, N. V., Fraser, J. M., \& Amold, R. L. (1996). Teaching academies: Honoring and promoting teaching through a community of expertise. In M. D. Svinicki \& R. J. Menges (Eds.), Honoring exemplary reaching (New Directions for Teaching and Learning No. 65) (pp.25-32). San Francisco: Jossey-Bass.

Chism, N. V., \& Lumpkins, T. (1995). The great TA program evaluation question: The pragmatic response of one center. In T. A. Heenan \& X. F. Jerich (Bds.), Conference proceedings: The 4th national conference on the education and employment of graduate teaching assistants (pp. 169-174). University of Illinois, Urbana-Champaign, II.

Chism, N. V., \& Szabó, B. L. (1996). Evaluation of the departmental teaching excellence awards program. Columbus, OH: The Ohio State University Center for Teaching Excellence.

Eble, K. E. (1983). The aims of college teaching. San Francisco: Jossey-Bass.

Edgerton, R. (1993). The re-examination of faculty priorities. Change, 10-25.

Erickson, G. (1986). A survey of faculty development practices. In M. Svinicki, J. G. Kurfiss, \& J. Stone (Eds.), To Improve the Academy, Vol. 5 (pp. 182-196). Stillwater, OK: New Forums Press.

Forsythe, G. B., \& Gandolfo, A. (1996). Promoting exemplary teaching: The case of the U.S. In M. D. Svinicki \& R. J. Menges (Eds.), Honoring exemplary teaching (New Directions for Teaching and Learning No. 65) (pp. 99-104). San Francisco: JosseyBass.

Gray, P. J., Diamond, R. M., \& Adam, B. E. (1996). A national study of the relative importance of research and undergraduate teaching at colleges and universities. Syracuse, NY: Syracuse University Center for Instructional Development.

Green, M. F. (1990). Why good teaching needs active leadership. In P. Seldin (Ed.), How administrators can improve teaching (pp. 45-62). San Francisco: Jossey-Bass.

Jacobsen, R. H. (1989, March). The impact of faculty incentive grants on teaching effectiveness. Paper presented at the Annual Meeting of the American Educational Research Association, San Francisco.

Jenrette, M., \& Hays, K. (1996). Honoring exemplary teaching: Two-year college setting. In M. D. Svinicki \& R. J. Menges (Eds.), Honoring exemplary teaching. (New Directions for Teaching and Leaming No. 65) (pp.77-84). San Francisco: JosseyBass.

Kahn, S. (1996). Awards to groups: The university of Wisconsin system's departmental teaching award. In M. D. Svinicki \& R. J. Menges (Eds.), Honoring exemplary teaching. (New Directions for Teaching and Learning No. 65) (pp. 11-16). San Francisco: Jossey-Bass.

Ling, L., \& Ling, P. (1994). Administration for innovation in higher education. Innovative Higher Education, 18, 221-236.

lopez, 8. \& Chism, N. V.N. (1991). Evaluation of the success stories program. Columbus, OH: The Ohio State University Center for Teaching Excellence. 
Lortie, D. (1975). Schoolteacher. Chicago, Il: University of Chicago Press.

Lunde, J. P., \& Barrett, L. (1996). Decentralized/Departmental reward systems. In M. D. Svinicki \& R. J. Menges (Eds.), Honoring exemplary teaching. (New Directions for Teaching and Learning No. 65) (pp. 93-98). San Francisco: Josecy-Bass.

Mauksch, H. O. (1987). The context of preparing teaching assistants. In N. V. N. Ghism \& S. B. Warner (Eds.), Employment and education of teaching assistants (pp. 14-18). Columbus, OH: The Ohio State University Center for Teaching Excellence.

McNaught, C., \& Anwyl, J. (1993). Awands for teaching at Australinn universities. Centre for the Study of Higher Education Research Working Papers 93.1. Melbourne, Australia: Melboume University.

Menges, R. J. (1996). Awards to individuals. In M. D. Svinicki \& R. J. Menges (Eds.), Honoring exemplary teaching (New Directions for Teaching and Learning No. 65) (pp.3-10). San Francisco: Jossey-Bass.

Paulsen, M., \& Feldman, K. (1995). Taking teaching seriously (ASHE-ERIC Higher Education Report No 2). Washington, DC: The George Washington University.

Poirier, F. E., \& Sell, G. R. (1989). The meaning and significance of faculty awards at Ohio State. Notes on Teaching, 2.

Schwartz, C. (1992). Is good teaching rewarded at Berkeley? College Teaching, 40, 33-36.

Scriven, M. (1973). Goal-free evaluation. In E. R. House (Ed.), School evaluation: The politics and process. Berkeley, CA: McCutchan.

Spence, J. T., \& Helmreich, R. L. (1983). Achievement-related motives and behavior. In J. T. Spence (Ed.), Achievement and achievement motives: Psychological and sociological approaches. New York: Freeman.

Smith, H. L., \& Walvoord, B. E. (1993). Certifying teaching excellence: An alternative paradigm to the teaching awand. American Association for Higher Education Bulletin, 11, 2-12.

Sorcinelli, M. D., \& Davis, B. G. (1996). Honoring exemplary teaching in research universities. In M. D. Svinicki \& R. J. Menges (Eds.), Honoring exemplary teaching (New Directions for Teaching and Leaming No. 65) (pp. 71-70). San Francisco: Jossey-Bass.

Sowell, T. (1990). On the higher learning in America: Some comments. The Public Interest, 99, 68-78.

Svinicki. M. D. (1995). The seven deadly comments that get in the way of learning about teaching. In T. A. Heenan \& K. F. Jerich (Eds.), Conference proceedings: The 4th national conference on the education and employment of graduate teaching assistants (pp. 13-18). University of Illinois, Urbana-Champaign, II.

Svinicki, M. D., \& Menges, R. J. (1990). Consistency within diversity: Guidelines for programs to honor exemplary teaching. In M. D. Svinicki \& R. J. Menges (Eds.), Honoring exemplary teaching (New Directions for Teaching and Learning No. 65) (pp. 109-114). San Francisco: Jossey-Bass.

Uhlig, G., \& Haberman, M. (1987). A study of faculty development practices in schools, colleges and departments of education. Alabama: Research Report. 


\section{Teaching Awards}

Weimer, M. (1990). Improving college teaching. San Francisco: Josey-Bass.

Zahorski, K. J. (1996). Honoring exemplary teaching in the liberal arts institution. In M. D. Svinicki \& R. J. Menges (Eds.), Honoring exemplary teaching (New Directions for Teaching and Learning No. 65) (pp. 85-92). San Francisco: Jossey-Bass.

\section{Contact:}

Nancy Van Note Chism

Director, Faculty and TA Development

The Ohio State University

20 Lord Hall

124 West 17th Avenue

Columbus, OH 43210

(614) 292-3644

(614) 688-5496 FAX

chism.1@osu.edu

Nancy Chism is Director of Faculty and TA Development at The Ohio State University and an adjunct faculty member in the Department of Educational Policy and Leadership. She was President of the Professional and Organizational Development Network in Higher Education in 1995-96 and is currently Ameritech Faculty Fellow at Ohio State. Her interests include multicultural teaching; teaching assistant development; research, evaluation and assessment strategies; and educational technology.

Borbála Szabó is a graduate student in Physical Activities and Educational Services at The Ohio State University. She is currently writing her dissertation in her area of interest, rehabilitation services for children. Between 1994 and 1997, she was a graduate research associate with Faculty and TA Development and worked on research projects focused on evaluation of faculty development interventions, professional development needs of faculty developers, and the use of electronic mail in teaching. 